\title{
Circuit
}

Musiques contemporaines

\section{Finger Exercises for Oscillators: István Anhalt on Electronic Music}

\section{Matt Rogalsky}

Volume 19, numéro 3, 2009

Pionniers canadiens de la lutherie électronique

URI : https://id.erudit.org/iderudit/038260ar

DOI : https://doi.org/10.7202/038260ar

Aller au sommaire du numéro

Éditeur(s)

Les Presses de l'Université de Montréal

ISSN

1183-1693 (imprimé)

1488-9692 (numérique)

Découvrir la revue

Citer cet article

Rogalsky, M. (2009). Finger Exercises for Oscillators: István Anhalt on Electronic Music. Circuit, 19(3), 77-84. https://doi.org/10.7202/038260ar
Résumé de l'article

Le compositeur István Anhalt discute avec l'auteur de son association avec Hugh Le Caine et avec les laboratoires du Conseil national de recherches du Canada dans les années 1950, de la fondation du studio de musique électronique de McGill et de ses premières expériences d'apprentissage de la musique sur bande et de la synthèse analogique. Le compositeur décrit ses premières oeuvres électroniques, parle de l'utilisation d'éléments électroacoustiques dans ses oeuvres plus récentes et de l'importance de la musique électroacoustique dans le contexte de l'éducation musicale. 


\section{Finger Exercises for Oscillators: István Anhalt on Electronic Music ${ }^{1}$}

Matt Rogalsky

The McGill studio became a reality in the summer of 1964 when Gordy Ellis and René Farley drove some equipment received from the National Research Council (NRC) in Ottawa. The little McGill studio was in the idyllic coach house in the garden of the Faculty of Music building on Redpath Street. We had two Ampex recorders, a number of Hugh Le Caine's inventions, and I was on my own. We had no money, until Helmut Blume, an enthusiastic supporter of the idea of a studio, became Dean of Music. The fact that McGill now boasts the largest faculty of music in the country is due to his work. $\mathrm{He}$ was a dynamo. I feel he has not received enough credit for all the good work he did.

But, I have to backtrack.

I first became interested in electronic music in 1956 or 1957. Helmut Blume produced a series of broadcasts of European avant-garde music, and played the Stockhausen Studie and also Gesang der Jünglinge. It totally blew my mind and I went to the CBC the next day and got permission to listen again. The whole concept was so novel, combining the voice of that boy, together with electronic generated sounds which were new to me. I was really smitten by that. Soon after, through a colleague at McGill's Physics Department, I made contact with Hugh Le Caine who invited me over to the NRC.

I spent a very stimulating yet frustrating day at the NRC. Hugh was this giant of a man who didn't look at you when he talked. He looked away and spoke in a monotone. It was very difficult to understand him, so I had to strain, and I got a headache in the process. And all that was in this chaotic room, which you cannot imagine. It was a large room full of tables of different sizes on which equipment was piled in great profusion and great
1. Remarks culled from an interview in the composer's home in Kingston, Ontario on 12 February 2009 
confusion. It was quite an experience. Hugh played me the piece Dripsody, which I think is a wonderful conception and shows great skill and great musicality. I mean, just a drop of water in the bucket, recorded to perfection, and then expanded into cascades of sounds, enormous arpeggios. I think technologically and technically it's a wonderful piece. Hugh studied music at the Royal Conservatory and he was a very musical man, but also overly modest.

Then in 1958 I received a grant and travelled to Europe. I spent a day in Paris with Pierre Schaeffer's outfit, which was frustrating because he had a visitor from Russia and was more interested in the Russian visitor than the Canadian visitor. But then I went on to Cologne and found Stockhausen, and Gottfried Michael Koenig. Koenig was very helpful. At that time he had just finished composing Klangfiguren, which is a good piece, purely electronic, and I was kind of quizzing him about his techniques. He was very forthcoming, very informative, and we spent the whole week, with him showing me bits and pieces of Klangfiguren. I really had a lesson in one way of making electronic music.

There was also an informative afternoon which I spent in the Cologne studio about a year or two later with Stockhausen and Cornelius Cardew, a very interesting man who was then Stockhausen's assistant. Either Stockhausen invited me, or I invited myself because I wanted to know how he worked. So there were the three of us in the Westdeutscher Rundfunk Studio. Stockhausen had a series of notes with him, and he read out from his notes: so many centimetres long of a recording of pulse train, or sine tone, filtered white noise or whatever. He had it all figured out, what he wanted. Cardew, the assistant, did what Stockhausen told him to do, and he was quick. After Cardew ran the experiment, Stockhausen declared "let's keep it" or he'd say "junk, throw it out." It was very much by ear, and very methodical. Just as methodical as Koenig was in his Klangfiguren. Most people working there knew exactly what they were after and they worked by trial and error. The WDR studio was no comparison to the diversity eventually offered by the McGill studio. They had one four-track tape recorder, two two-track tape recorders, a pulse code generator, a few sine tone generators, a white noise generator, a few filters. It was a pretty primitive setup, but Stockhausen knew exactly what he wanted to do.

For quite a number of years, Hugh (Le Caine) was the star of the building at the National Research Council which housed its electrical engineering division. A fairly large building, three floors. That's where Hugh's ELMUS lab, the electronic music laboratory at the NRC, was and that's where I 
worked. I had to use earphones because it was a building with many people doing different kinds of work. But come 5 o'clock when people went home, I could take off the earphones and blast away since I was then the only person working there.

When I encountered the technology of the lab, I had to learn my finger exercises, getting to know the different machines. I had a great deal of help from Hugh and his two technicians. For example I needed an echo chamber, and there was none, so I declared one of the loos to be an echo chamber. Of course from time to time there was a toilet flush, but at 5 o'clock the flush was turned off. We set up two microphones. The first mic picked up sounds which I was making in the studio, which were played back through a loud speaker in the loo, and the other mic picked it up. Together with the echoes, minus the flushing of the toilet. I think it was wonderful.

Then I got the shortest lesson in electronic music technology from Gordy Ellis. I still remember the one sentence: "Don't touch the equipment with both hands." Many of the things were not grounded, and you didn't want to be electrocuted. So I observed his advice and as you can see I'm sitting here, alive. Up to a point.

The ELMUS lab was very busy. All sorts of projects were being conducted. When I first came to see Hugh, he took me to see the then director of the electrical engineering division, and I expressed an interest to come back and work there. I was appointed as visiting scientist, if you can imagine. They gave me a small stipend even. It was the biggest joke-I was a visitor, but no scientist. So I came there with my dear wife and two little children who toughed it out in Ottawa, which was a hick town at that time. My working day started at 11 o'clock in the morning, and I worked until five in the afternoon with earphones. Then I would have supper at home, and come back and work until two or three in the morning without earphones. I was totally on my own, and I made four electronic music pieces. The first was nothing-I should not even consider it a piece. I was just playing around with pulse tone generators. The second, third, and fourth, however, I think they are pieces.

Eventually, Hugh left me alone. He really kept out of my way and expected me to keep away from him. He was satisfied to have me work in the studio, but you see, by that time the whole unit, the electrical engineering unit changed. Hugh had been the star-for instance, when the Prince of Wales visited the NRC, they trotted out Hugh. But when eventually computers became a reality, his star faded and I cannot help but feel that Hugh felt useless, outdated, obsolete. It was tragic. For him work was so central to 
existence, that he could not think of continuing living. I mean this accident with a motorcycle, where he was killed... I have no proof, but I think it might have been a suicide.

I stopped working at the NRC lab in 1962 . I think that was the last year. But by then I had the equipment at McGill so I could do everything there.

In 1961 or 1962 I spent a month in New York at the Columbia-Princeton Centre, with the RCA synthesizer. It was a huge machine, but I couldn't really make it work. The only person in my experience who could make the RCA electronic synthesizer work was Babbitt, who did a number of good pieces. After New York, I had an appointment at Murray Hill, at Bell Labs. I worked with Max Mathews for a whole week. He was able to synthesize little pieces using the 7090 computer which was huge, almost as big as a whole wall. The sounds which came out were mousey little sounds, but anyhow it was interesting. I recorded a few sounds with the 7090, and you can hear them at the beginning of my piece Foci (1969).

When I finished at Bell Labs, I felt I had to make up my mind whether I wanted to go whole hog into computer music. By that time I was very much interested in language, linguistics, which was a lot of learning for me. I spent much of the 1960s learning about language. Cento (1967) is one piece in which I combined sounds uttered by the mouth, together with electronic sounds. Foci is another.

Cento was fun to do, but a bit time consuming. I had a thousand tape loops. I was interested in combining bits of language. I had no methodology, but I imagined a fantastic collage of language sounds generated on the basis of selecting voices and inventing words or linguistic continuities. I selected about a dozen speakers including the poet Eldon Grier, whose huge poem "An Ecstasy" became a mine of stuff from which I selected words and sentences, bits and pieces. Then I selected speakers, male, female, old, young, and coached them and had them utter bits and pieces of language according to what I wanted to hear.

I recorded those bits and pieces on about a thousand tape loops, which I played back mainly through Hugh Le Caine's multi-track recorder. McGill had one version, and Queen's had another version (later both McGill and Queen's donated their versions of the multi-track to scientific morgues). Those thousand tape loops held both the raw material and the idiosyncratic tone colours of the speakers. To me they were a giant orchestra. The problem was how to find your way among a thousand tape loops. Well, I memorized a number of them - of course not all of them - and I tried to keep track of what I had. Kevin Austin helped me. He was an enthusiastic assistant of mine. He 


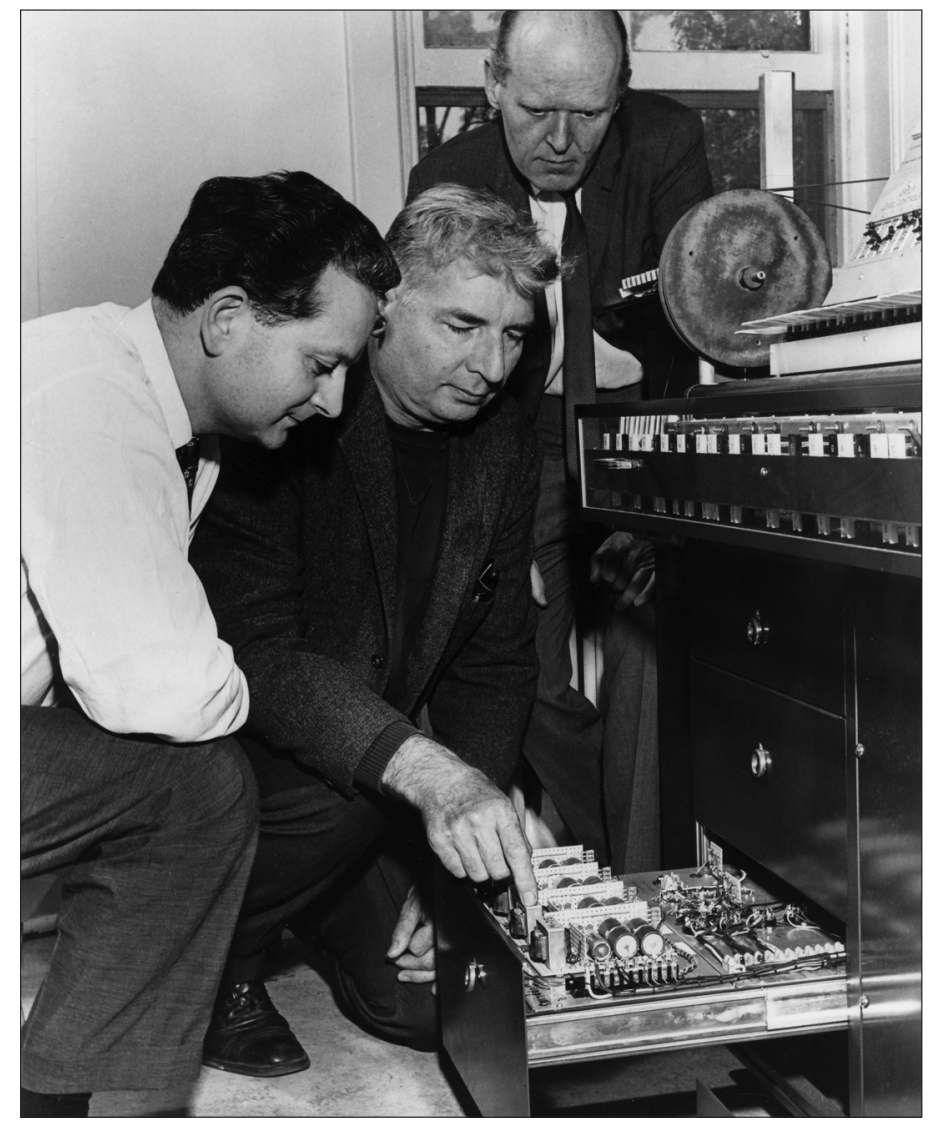

Hugh Le Caine (centre) demonstrates the internal controls of the 1961 version of the multi-track tape recorder to István Anhalt (left) and Helmut Blume (back) of the Faculty of Music of McGill Univeristy - 1964.

(C) Conseil national de recherches Canada. Reproduite avec la permission du ministre des Travaux publics et Services gouvernementaux Canada (2009). Source: Bibliothèque et Archives Canada/Fonds Hugh Le Caine.

became very good, and at one point he made a statement that "by the late sixties I became better than Anhalt. He had better ideas, but technically I became better." And I think he had the right to say that because it was true.

In the process of composing Cento, I had of course the tape part, but I also had twelve live vocalists, so then it was a question of how I was going to coordinate the two. Of course the tape was immutable, so it means the singers or the speakers had to adjust. There is a time score. The tape runs, and the twelve vocalists have their individual utterances. These are taken from a repertory of raw material from which everything was derived, so it worked with the recorded part. 
By that time I was not so much interested in purely electronic sounds, but I was interested in hybrids, because of my research into language. I was trying to invent my own work procedure.

Working on La Tourangelle (1975) was a great experience. I tried to invent the words of Marie de l'Incarnation, an enormously complex woman. The work ended up focusing on only the first half of her life because when I was thinking of writing a sequel, I wanted to use the language of the Hurons, using Huron speakers. I discovered that the last person who spoke the languagenot Huron, but Wyandot, because they called themselves Wyandots - the last Wyandot speaker was recorded by Marius Barbeau in 1916, somewhere in Oklahoma. So, there was nothing to go on and that's why La Tourangelle has only the first half of the life of Marie.

For La Tourangelle, there is a beautifully done score which also shows placement of conductor, orchestra, microphones, loudspeakers and three tape recorders. I was controlling the acoustic output, the loudness level in the auditorium. Each tape recorder had an operator who had to align the tapes, because there is leader in between sections of audio. There was a conductor for the three tape operators. It was quite an involved thing, but it worked. The tape parts are just an integral part of a huge whole. I was interested in trying to recreate the mentality of this complex woman. I mean it was much more exciting for me at that time, than just fussing only with tape recorders.

Somehow at one point I sensed the limitedness of what I could do with electronic sound. I don't say limitedness period, because some other people who were more inventive than I was could go on, and I didn't pretend to be the touchstone of potentials or lack of potentials. But I got tired of it at one point and started to do other things. La Tourangelle is the largest thing I did, and I'm happy I did it. I spent five years on that and it was probably not too much time. The technology involved is such that I couldn't think of any other means by which I could bring to life a semblance of the persona of such a complex person.

Working with electronic music, with machines, alone in a studio, instead of with live performers, vocalists, instrumentalists - I felt that was a very liberating experience. I think that even when one runs an improvisation group with willing colleagues and so on, there is still an element of "Am I asking too much? Do they think I am crazy?" And there are always potential inhibitions. When you work in the studio, meaning an empty building, there are no raisons d'être for inhibitions. The machines are patient. They toler- 
ate everything as long as what you want them to do is compatible with their nature. So I thought that working in the electronic music studio for so many years was, in a strange way, an enormously liberating exercise. It liberated me to think in terms of doing similar things with string quartets, with string orchestras, with full orchestras, and I could invent all sorts of structures as long as they made sense. And so to me, advising a young composer, I would say "Well, you would be well-advised to spend some time with electronic music, working with machines, and doing things at your own speed. Go where your imagination might take you." I think it's an enormously liberating influence for a composer. The young composer who works in a studio with machines has to really enjoy that freedom and use it to the fullest possible extent, in order to derive the benefit of transferring that experience into working with human players who are not machines. I learned that in the studio.

For instance, my piece Sonance $\bullet$ Resonance (1989) is about Beethoven, his suffering from tinnitus and evolving the Ninth Symphony through some process. Well, I was trying to "compose" tinnitus, the ringing of the ears, so I used four percussion instruments and a lot of clangy instruments. It was fun to write, but when I came to The Tents of Abraham (2004), I said "I want to go beyond that and I don't think having 4 sets of crotales and 4 sets of bells is enough."

So I went with one of the percussionists of the Kingston Symphony to a junkyard, and I asked permission from the owner to gather up a few pieces of metal junk. We found some sets of tubular constructions which worked perfectly, so I gathered up quite a few of those and we stuck them up on coat hangers, on long chains. We had five percussionists whacking at them, and they made a fantastic sound.

So my experience with electronic music sort of opened up my imagination, but music is much more than a few pieces of equipment. It's how human beings relate to the equipment, what sounds they imagine first and how they find the equipment to produce the sounds, as in The Tents of Abraham.

However ingeniously conceived Hugh Le Caine's instruments were, they had their limitations. Those limitations really frustrated me. Now I can produce by an ordinary symphony orchestra, even a half-sized symphony orchestra, any sound I want, so I don't need to harken back. Hugh's machines did their bit for me, but music is more than any instrumentarium. I found that working with electronic generators was very exciting for me at that time. But now, to think of the capability of fifty-five musicians, each very well trained, each playing a beautiful instrument, if there is a harmonic language to go with it! And the timbral varieties are just astronomical, what a symphony 
orchestra can do. So I feel that I didn't regress, going back just to the symphony orchestra.

I'm not saying that I wasted my time doing the synthetic. I didn't. All those unusual sounds, combinations of sine tones, filtered white noise, they appealed to me. I wanted to learn about that. I could not have written a piece like ... the timber of those times... (2006) and evolving the harmony and grammar of my later pieces, if I had not acquired a compositional freedom which my work with synthetic music afforded me. It was an enormously liberating thing. But after I had been liberated sufficiently, I said "Enough." 